\title{
Comparison of Self-Esteem and Social Anxiety Levels of Adolescents Who Wear Spectacles and Who Do Not
}

\author{
Gözlük Kullanan ve Kullanmayan Adolesanların Benlik Saygısı ve Sosyal \\ Kaygı Düzeylerinin Karşılaştırılması
}

\author{
Duygu Yalınbaş Yeter ${ }^{1}$, Erman Bozali ${ }^{1}$, Ayla Uzun Çiçek ${ }^{2}$
}

\begin{abstract}
Introduction: Self-esteem and social anxiety could affect both the social life and school success of adolescents. Wearing spectacles in adolescence may be related to self-esteem and social anxiety. Therefore, in this study, we aimed to compare the level of self-esteem and social anxiety between adolescents who wear spectacles and those who do not. Methods: This comparative descriptive study which was conducted in Sivas Cumhuriyet University Ophthalmology outpatient clinic between March-July 2021, consisted of 108 adolescents who have been wearing spectacles for at least one year, and age and sex-matched, 150 healthy adolescents. Self-esteem was measured by Rosenberg Self-esteem Scale and social anxiety was measured by Social Anxiety Scale for Children-Revised. The socio-demographic characteristics of the participants and clinical data on spectacle were evaluated via a sociodemographic data form. Results: 69 (63.9\%) of the study group were girls, and the mean age was $12.92 \pm 1.55$ years. For the right eyes, the mean spherical equivalent (SE) value was $1.10 \pm 3.23 \mathrm{D}$ and it was $-1.15 \pm 3.39 \mathrm{D}$ for the left eyes. The mean self-esteem scores of the spectacle wearers were significantly lower $(22.53 \pm 4.60$ vs. $25.50 \pm 2.05, \mathrm{p}<0.001)$, and the mean social anxiety scale scores were significantly higher $(40.23 \pm 10.90 \mathrm{vs} .36 .13 \pm 7.57$, $\mathrm{p}=0.006)$ compared the control group. When the patients were evaluated as myopic $(n=78)$ and hyperopic $(n=30)$ regarding the $S E$, even though there was an increase in the social anxiety score as the degree of myopia increased for both eyes (for right, $r=.-280, \mathrm{p}=0.01$, and for left, $r=.235, p=0.04)$, there was no significant correlation with self-esteem scores $(p>0.05)$. Conclusion: Wearing spectacles in adolescence seems to be related to self-esteem and social anxiety. An appropriate approach would be to perform a thorough psychological evaluation of adolescents who wear spectacles.
\end{abstract}

Keywords: Self-esteem, social anxiety, wearing spectacles, adolescent

\section{ÖZET}

Giriş: Benlik saygısı ve sosyal kaygı, adolesanların hem sosyal yaşamını hem de okul başarısını etkileyebilir. Adolesan döneminde gözlük takmak benlik saygısı ve sosyal kaygı ile ilişkili olabilir. Bu nedenle bu çalışmada gözlük kullanan ve kullanmayan adolesanların benlik saygısı ve sosyal kaygı düzeylerini karşılaştırmayı amaçladık. Yöntem: Mart-Temmuz 2021 tarihleri arasında Sivas Cumhuriyet Üniversitesi Göz Hastalıkları polikliniğinde yürütülen bu karşılaştırmalı tanımlayıcı çalışmanın örneklemini, en az bir yıldır gözlük takan 108 adolesan ile yaş ve cinsiyet açısından eşleştirilmiş 150 sağlıklı adolesan oluşturdu. Benlik saygısı Rosenberg Benlik Saygısı Ölçeği ile ve sosyal kaygı, Çocuklar İçin Sosyal Kaygı Ölçeği- Yenilenmiş Biçim ile ölçüldü. Katılımcıların sosyo-demografik özellikleri ve gözlükle ilgili klinik verileri, bir sosyodemografik veri formu aracılığıyla değerlendirildi. Bulgular: Çalışma grubunun 69'u (\%63,9) kız olup, yaş ortalaması $12,92 \pm 1,55$ yıl idi. Sağ göz için ortalama sferik eşdeğer (SE) değeri $-1.10 \pm 3.23 \mathrm{D}$, sol göz için $-1.15 \pm 3.39 \mathrm{D}$ idi. Kontrol grubu ile

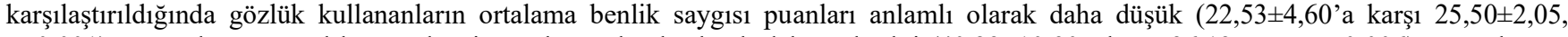
$\mathrm{p}<0,001)$ ve ortalama sosyal kaygı ölçeği puanları anlamlı olarak daha yüksekti $(40,23 \pm 10,90$ 'a karş1 $36,13 \pm 7,57, p=0,006)$. Hastalar SE açısından miyop $(n=78)$ ve hipermetrop $(n=30)$ olarak değerlendirildiğinde her iki gözde miyopi derecesi arttıkça sosyal anksiyete puanında artış olmasına rağmen (sağ için, $\mathrm{r}=.-280, \mathrm{p}=0.01$ ve sol için, $\mathrm{r}=.-235, \mathrm{p}=0.04$ ), benlik saygısı puanları ile anlamlı bir ilişki yoktu ( $\mathrm{p}>0.05$ ). Sonuç: Adolesan döneminde gözlük takmanın benlik saygısı ve sosyal kaygı ile ilişkili olduğu görülmektedir. Gözlük takan adolesanların kapsamlı bir psikolojik değerlendirmesini yapmak uygun bir yaklaşım olabilir.

Anahtar kelimeler: Benlik saygıs1, Sosyal kaygı, Gözlük kullanma, Adolesan.

Received / Geliş tarihi: 31.07.2021, Accepted / Kabul tarihi: 27.10.2021

${ }^{1}$ Cumhuriyet University Faculty of Medicine, Department of Ophthalmology, Sivas, Turkey

${ }^{2}$ Cumhuriyet University Faculty of Medicine, Department of Child and Adolescent Psychiatry, Sivas, Turkey

*Address for Correspondence / Yazışma Adresi: Duygu Yalınbaş Yeter, Cumhuriyet University Faculty of Medicine, Department of Ophthalmology, Sivas, TURKEY, E-mail: duyguyalinbas@gmail.com

Yalınbaş Yeter D, Bozali E, Uzun Çiçek A. Comparison of Self-Esteem and Social Anxiety Levels of Adolescents Who Wear Spectacles and Who Do Not. TJFMPC, 2021;15(4): 862-871.

DOI: $10.21763 /$ tjfmpc.976914 


\section{INTRODUCTION}

Undercorrected refractive error is one of the most common causes of visual impairment in all age groups and it influences approximately 88.4 million individuals with moderate or severe distance vision impairment or blindness. $\frac{1}{}$ The distribution of the frequency of refractive errors such as myopia, hyperopia, and astigmatism differs between countries and age groups. Ethnic, genetic, environmental factors and lifestyle changes play a role in this context. $\stackrel{2}{=}$

The progression and frequency of myopia have been increasing recently due to increased screen time, long periods of near working, and a decrease in the time spent outdoors. The increase in the onset and progression of myopia in the pediatric age group together with the increase in the use of digital devices due to the restrictions for the COVID19 pandemic also supports this. ${ }^{3}$ Spectacle use is the preferred treatment method in the correction of refractive errors in children since it is a low-risk intervention and more cost-effective compared to contact lenses or surgical intervention. .4 Along with the increase in refractive error, the frequency of spectacle use increases in children and adolescents. The estimated frequency of spectacle use in childhood ranges from $6 \%$ to $35 \%$.

Physical appearance and attractiveness are important factors for having high self-esteem in childhood and adolescence. In previous studies, conditions affecting appearances such as obesity and facial malformations are determined to be substantial on self-esteem. $\underline{6}, \underline{7}$ Spectacle use in children also affects appearance for a long period. Studies conducted in adults report that people who wear spectacles are appraised as more intelligent, hardworking, authoritative, but less attractive. $\underline{5}$ Studies evaluating the relationship between spectacle use and self-concept and esteem in children and adolescents demonstrated controversial findings. Odedra et al. reported that $15 \%$ of children with correctable vision problems felt that their spectacles made them look silly. ${ }^{-}$In another study, the authors reported that children who wear spectacles are appraised as more intelligent than those who do not wear spectacles. ${ }^{9}$ Lyon et al., on the other hand, stated that there was no difference in terms of self-perception between children who wear spectacles and those who do not. $\underline{10}$

Self-esteem is a positive state that provides self-confidence by confirming one's worth. $\underline{11}$ Far beyond shyness, social anxiety is a fear of excessive worrying about social situations that impacts daily activities, especially social activities, selfconfidence, relationships, work, or school life. It is known that children and adolescents with high social anxiety levels also have lower self-esteem. $\frac{12}{2}$ Studies conducted in children and adolescents with a social anxiety disorder (social phobia) reported that these children may have lower self-confidence, higher level of anxiety and depression, and experience peer and school problems more frequently. $\frac{13}{\text { In addition, }}$ a negative relationship between self-esteem and social anxiety disorder has been reported where children with high self-esteem had lower social anxiety level. $\underline{14}$ A perception or thought that the use of spectacles during adolescence, where physical appearance becomes important, impairs physical attractiveness and is embarrassing may negatively affect self-esteem and cause over worrying and anxiety in social situations. Unfortunately, few studies investigate the relationship between wear spectacles and self-esteem in the adolescent population and, as outlined above, these have yielded conflicting findings. Again, to our knowledge, there are limited published data in the field on social anxiety for adolescents who wear spectacles. Given that adolescence is a critical period of development in the life course and wearing spectacles in this population is common, it is possible that wearing spectacles may affect adolescent's thoughts about himself/herself positively or negatively. Therefore, it is of utmost importance for parents, teachers and health professionals to be aware of whether wearing spectacles has an impact on adolescent self-esteem and social anxiety.

In the present study, we sought to address the limitations of previous studies. Thus, the purpose and the outcomes of the present study are twofold and may further bridge this gap. The primary aim is to compare the level of self-esteem and social anxiety between adolescents who wear spectacles and those who do not. The secondary aim is to reveal/determine the self-perception of adolescents who wear spectacles and the difficulties they may experience due to wearing spectacles.

\section{MATERIALS AND METHODS}

\section{Study Design and Participants}

This comparative descriptive study was conducted in the outpatient clinic of the Department of Ophthalmology, Sivas Cumhuriyet University between March and July 2021. The subjects for this study consisted of 108 adolescents between the ages of 11-16 who have been wearing spectacles for at least one year, and age and sex-matched, 150 adolescents with similar sociodemographic features who never wore spectacles and had no ocular or visual complaints. Initially, 154 adolescents were enrolled, but 46 adolescents were dropped out for the following reasons: 28 adolescents/parents refused to participate (22 of them due to parents' shortage of 
time and 6 adolescents/parents declared that the study is useless for themselves) and 18 adolescents were excluded because they did not meet the inclusion criteria. Adolescents in the control group were randomly selected from adolescents who applied to the outpatient clinic of the Department of Pediatrics of the same hospital for healthy child follow-up and from relatives of hospital staff.

\section{Data Collection and Procedure}

Participants potentially eligible for participation were identified by a trained and certified child and adolescent psychiatrist and two ophthalmologists. All questionnaires and scales were collected face-toface from the participants. All participants underwent a complete ophthalmic examination including pupil reactions, intraocular pressure measurement, best-corrected visual acuity (BCVA) assessment (measured by Snellen), slit-lamp biomicroscopy, dilated fundus examination, and cycloplegic refraction measurements by an auto refractometer, Tonoref II (Nidek Co. Ltd, Gamagori, Japan). Then, Diagnostic and Statistical Manual of Mental Disorders, Fifth Edition (DSM-5) criteria were used to determine whether any present or past psychopathology is present via face-to-face interviews with all participants and their parents. $\frac{15}{}$ The best estimate DSM-5 diagnoses were based on in-depth and unstructured personal interviews as well as interviews with family members conducted by trained and certified child and adolescent psychiatrists which typically lasts about half an hour. Patients with a history of psychiatric disorders that is determined by a child and adolescent psychiatrist, any chronic disease collected from adolescents' own and parents' anamnesis and medical records, who have a major physical disability affecting physical appearance (such as using a wheelchair, loss of limb, and significant facial malformations, etc.), and obesity were excluded from the study. We also excluded adolescents with a history of ocular diseases (except refractive errors) such as strabismus, glaucoma, uveitis, optic neuropathies, retinopathy, usage of ocular drugs, ocular trauma, and ocular surgery.

\section{Ethical Principles}

Parents/legal guardians of the adolescents were verbally informed about the purpose and procedure of the study. Written and verbal informed consent was obtained from legal guardians. This study was approved by the Sivas Cumhuriyet University Faculty of Medicine Local Ethics Committee (Date: 10.02.2021, No: 2021-02/23) and was in accordance with Good Clinical Practice guidelines and the current revision of the Declaration of Helsinki.
Sociodemographic Data Form: The form is specifically designed by the authors, considering the literature data regarding the purpose of the study. The form includes questions evaluating the sociodemographic characteristics of the participants including age, gender, place of residence, age and levels of education of the parents, family income, academic performance of participants. This questionnaire also includes questions that evaluate the clinical data on the spectacle wear, such as the duration of spectacle wear, how a refractive error was detected, type of the refractive error, presence of amblyopia, presence of individual(s) wearing spectacles in the close social circle, enjoying wearing spectacles, difficulties wearing spectacles, difficulties due to spectacles while playing sports, thinking spectacles suit one's self, thinking that spectacles distort one's facial appearance, being ridiculed for spectacle use, seeing better with spectacles, wearing a mask makes it difficult to use spectacles, increased prescription in the last year, enjoying having their eyes checked, the frequency of having eyes checked. These parameters were evaluated by the researchers via ophthalmic examination of the participants and during interviews with adolescents and their parents.

Rosenberg Self-esteem Scale (RSES): The Rosenberg self-esteem scale consists of 63 items. In this study, the first 10 items were used. This scale developed by Rosenberg $\underline{16}$ was adapted and validated for Turkish adolescents by Çuhadaroğlu. $\underline{17}$ It is a scale used to evaluate the positive and negative aspects of self-esteem. The validity coefficient was found as 0.71 and the reliability coefficient as 0.75 , and the Cronbach alpha reliability coefficient of the scale was .76 in this study. In this study, we utilized the self-esteem subtest, which is a 4-point Likert scale $(0=$ strongly disagree, $1=$ disagree, $2=$ agree, $3=$ strongly agree) consisting of 10 items and measuring the positive and negative aspects of selfesteem. The scale ranges from 0-30 and a high score indicates high self-esteem.

Social Anxiety Scale for ChildrenRevised (SASC-R): This 10-item scale, whose original form was developed by La Greca et al. in 1988, was based on self-report and was revised in 1993 and the number of questions was increased to 18. $\underline{18}$ Two components are evaluated in the scale: fear of negative evaluation and social distress. The score that can be obtained from the five-point Likerttype scale varies between 18-90. The Turkish adaptation, validity, and reliability of the scale were performed by Demir et al. in 1998. $\underline{19}$ Internal consistency and test-retest correlations for the Turkish version of the scale were found to be high $(\alpha=0.813, r=0.8096$, respectively). The Cronbach

\section{Data Collection Tools}


alpha reliability coefficient of the scale was 0.80 in this study.

\section{Statistical Analysis}

Analyses were performed using Statistical Package for the Social Science software for Windows (SPSS version 26.0, IBM Corporation, Armonk, NY, USA), and quantitative data were given as arithmetic mean and standard deviation (SD), qualitative data as number and percentage (n,\%). KolmogorovSmirnov test was used to test the compatibility of the data to normal distribution. Categorical variables were analyzed with the chi-square $(\chi 2)$ test, and the Kruskal Wallis Test and Mann-Whitney U test were used to compare the measurement variables between groups. Spearman correlation analysis was used to evaluate the relationship between refractive error and RSES and SASC-R scores. A p-value of $<0.05$ was considered statistically significant.

\section{RESULTS}

Sociodemographic Characteristics of the Sample

The study sample consisted of 108 adolescents aged 11-16 years who wore spectacles for at least one year (study group) and 150 adolescents who never wore spectacles (control group). Of all the participants in the study group, $63.9 \%$ were girls $(n=69), 36.1 \%$ were boys $(n=39)$, and the mean age was $12.92 \pm 1.55$ years (min-max: 11-16 years). Of the adolescents in the control group 58\% $(n=87)$ were girls and $42 \%$ were boys $(n=63)$, and the mean age was $13.04 \pm 1.84$ years (min-max: 11-16 years). There was no significant difference between the two groups in terms of age, gender, parental education level, family income, place of residence, and academic performance ( $p>0.05$ for all). The sociodemographic characteristics of the participants are given in Table 1 .

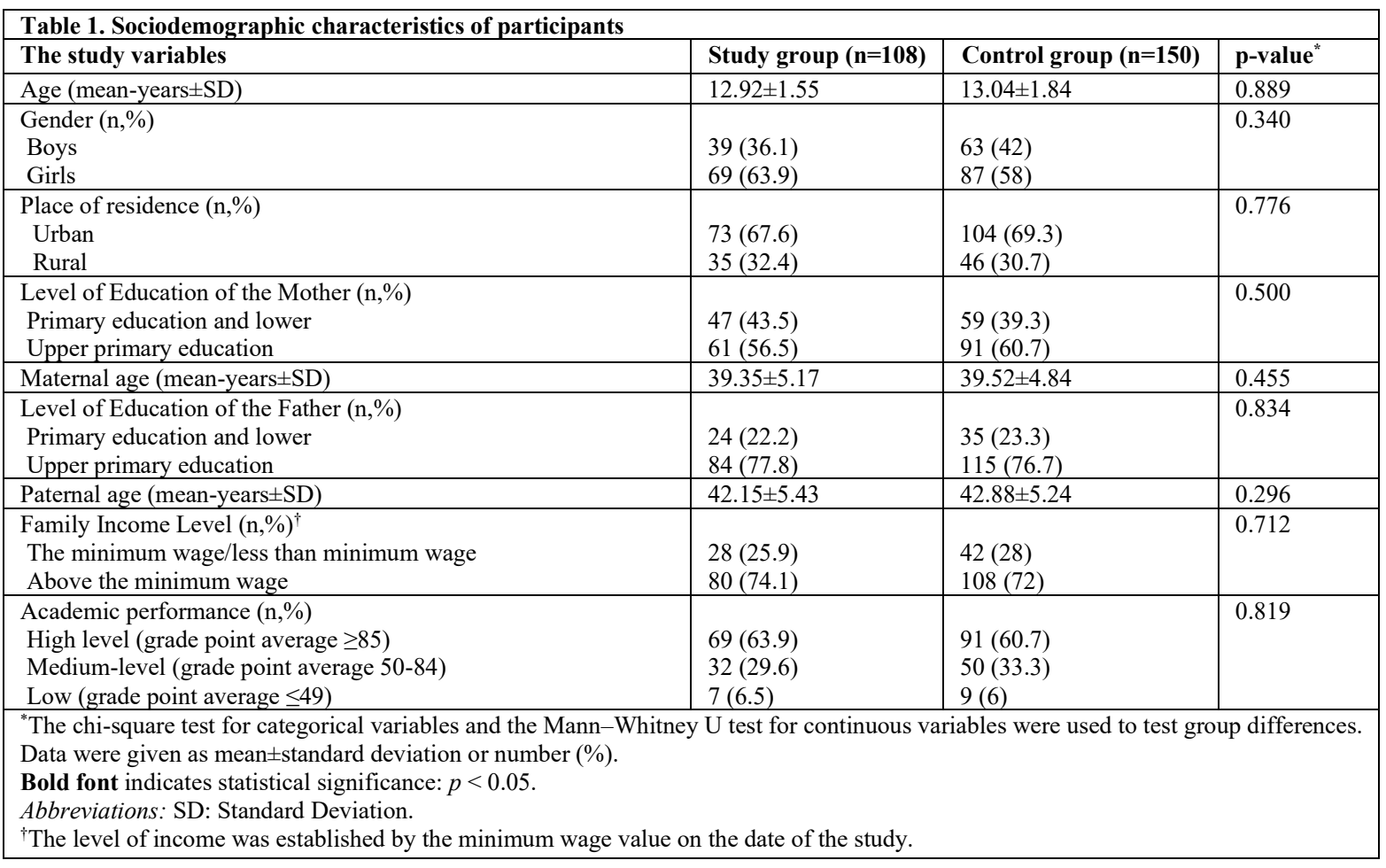

\section{Clinical Features Regarding Eye Disorder and Wearing Spectacles}

The mean duration of wearing spectacles was $4.12 \pm 2.52$ years (min-max: 1-12 years) and the average age of onset for wearing spectacles was $8.9 \pm 2.8$ years (min-max: $1-15)$ years. Of those with vision problems, $38.9 \%(\mathrm{n}=42)$ were noticed by parents, $31.5 \%(n=34)$ by teachers or by a doctor at school screening, $21.3 \%(\mathrm{n}=23)$ by themselves, and $8.3 \% \quad(n=9)$ by doctors during an ophthalmic examination. In addition to refractive error, amblyopia was present in $22(20.4 \%)$ of the adolescents who used spectacles. All but two of the adolescents with amblyopia had mild to moderate amblyopia and none of them were being treated with patching. Refractive error of spectacle wearers were as follows: myopia $(35.2 \%, \mathrm{n}=38)$, myopia + astigmatism $(33.3 \%, \quad \mathrm{n}=36), \quad$ hyperopia + astigmatism $(19.4 \%, \mathrm{n}=21)$, astigmatism $(6.5 \%$, $n=7)$, and hyperopia $(5.6 \%, n=6)$.

For the right eyes; the mean spherical power was $-0.97 \pm 2.8$ diopters (D), the mean cylindrical power was $-0.25 \pm 1.35 \mathrm{D}$ and the mean spherical equivalent (SE) value was $-1.10 \pm 3.23$ D. For the left eyes; the mean spherical power was $0.98 \pm 2.99 \mathrm{D}$, the mean cylindrical power was - 
$0.37 \pm 1.33 \mathrm{D}$ and the mean SE value was $-1.15 \pm 3.39$ D. The mean BCVA was $0.95 \pm 0.13$ (min: 0.30, max: 1.0 ) in the right eye and $0.93 \pm 0.17$ (min: 0.10 , max: 1.0) in the left eye (Table 2). Clinical features regarding the refractive error and wearing spectacles were summarized in Table 2.

\begin{tabular}{|c|c|}
\hline & Number $(\%)$ or mean \pm SD \\
\hline Spectacle wear duration (mean-years \pm SD) & $4.12 \pm 2.52(\min : 1, \max : 12)$ \\
\hline \multicolumn{2}{|l|}{ How was the refractive error detected? (n,\%) } \\
\hline Self & $23(21.3)$ \\
\hline Screening at school/Teacher & $34(31.5)$ \\
\hline Ophthalmic examination & $9(8.3)$ \\
\hline Parents & $42(38.9)$ \\
\hline Presence of amblyopia $(n, \%)$ & $22(20.4)$ \\
\hline \multicolumn{2}{|l|}{ Refractive error $(\mathrm{n}, \%)$} \\
\hline Myopia & $38(35.2)$ \\
\hline Hyperopia & $6(5.6)$ \\
\hline Astigmatism & $7(6.5)$ \\
\hline Myopia + Astigmatism & $36(33.3)$ \\
\hline Hyperopia + Astigmatism & $21(19.4)$ \\
\hline Right Spherical power (D) $(\operatorname{mean} \pm \mathrm{SD})$ & $-0.97 \pm 2.8$ (range: -8.50 to 8.0 ) \\
\hline Right Cylindrical power (D) $($ mean \pm SD) & $-0.25 \pm 1.35$ (range: -3.5 to 5.25$)$ \\
\hline Right Spherical Equivalent (D) $(\operatorname{mean} \pm \mathrm{SD})$ & $-1.10 \pm 3.23$ (range: -9.25 to 9.0 ) \\
\hline Left Spherical power $(\mathrm{D})($ mean \pm SD $)$ & $-0.98 \pm 2.99$ (range: -8.0 to 9.75 ) \\
\hline Left Cylindrical power (D) $($ mean \pm SD) & $-0.37 \pm 1.33$ (range: -5.0 to 3.75 ) \\
\hline Left Spherical Equivalent (D) (mean \pm SD) & $-1.15 \pm 3.39$ (range: -9.0 to 10.75 ) \\
\hline BCVA-Right (mean \pm SD) & $0.95 \pm 0.13$ (min: $0.30, \max : 1.0)$ \\
\hline BCVA-Left $($ mean \pm SD) & $0.93 \pm 0.17$ (min: $0.10, \max : 1.0)$ \\
\hline
\end{tabular}

BCVA: Best-corrected visual acuity, D: Diopters

\section{Other Clinical Features and Difficulties Associated with Wearing Spectacles}

There was at least one more individual wearing spectacles in the close social circle of $65.4 \%(n=68)$ of those who wore spectacles. Of those who wear spectacles, $61.1 \%(\mathrm{n}=66)$ declared that they do not enjoy wearing spectacles, 59.3\% $\quad(n=64)$ had problems with wearing spectacles, $68.5 \%(n=74)$ asserted that spectacles cause problems while doing sports, and $83.3 \%(n=90)$ complained about the difficulty to wear spectacles while using a mask within the scope of COVID-19 measures. Among those who wear spectacles, $63.9 \%(n=69)$ think that spectacles don't suit them, $41.7 \%(n=45)$ think that spectacles distort their facial features aesthetically, while $31.5 \% \quad(n=34)$ of them are ridiculed for wearing spectacles. Of those who wear spectacles, $4.6 \%(n=5)$ reported that their vision did not improve with spectacle use, and $39.8 \%(n=43)$ reported that their prescription increased in the last year. Of the who wear spectacles, $46.3 \%(n=50)$ had their eyes checked once every 6 months, $47.2 \%(n=51)$ once a year, and $6.5 \%(n=7)$ at least three times a year. $61.1 \%(n=66)$ reported that they did not like eye examination. Other clinical features and difficulties associated with wearing spectacles are given in Table 3.

\begin{tabular}{|l|l|}
\hline $\begin{array}{l}\text { Table 3. Other clinical features and difficulties associated } \\
\text { with wearing spectacles }\end{array}$ \\
\hline & Number (\%) \\
\hline $\begin{array}{l}\text { Individual wearing spectacles in the close } \\
\text { social circle (n,\%) }\end{array}$ \\
Yes & $68(65.4)$ \\
No & $36(34.6)$ \\
\hline
\end{tabular}

\begin{tabular}{|c|c|}
\hline $\begin{array}{l}\text { Enjoying wearing spectacles }(\mathrm{n}, \%) \\
\text { Yes } \\
\text { No }\end{array}$ & $\begin{array}{l}42(38.9) \\
66(61.1)\end{array}$ \\
\hline $\begin{array}{l}\text { Difficulties wearing spectacles }(\mathrm{n}, \%) \\
\text { Yes } \\
\text { No }\end{array}$ & $\begin{array}{l}64(59.3) \\
44(40.7)\end{array}$ \\
\hline $\begin{array}{l}\text { Difficulties due to spectacles while } \\
\text { playing sports }(n, \%) \\
\text { Yes } \\
\text { No }\end{array}$ & $\begin{array}{l}74(68.5) \\
34(31.5)\end{array}$ \\
\hline $\begin{array}{l}\text { Thinking spectacles suit one's self (n,\%) } \\
\text { Yes } \\
\text { No }\end{array}$ & $\begin{array}{l}39(36.1) \\
69(63.9)\end{array}$ \\
\hline $\begin{array}{l}\text { Thinking that spectacles distort one's } \\
\text { facial appearance }(\mathrm{n}, \%) \\
\text { Yes } \\
\text { No }\end{array}$ & $\begin{array}{l}45(41.7) \\
63(58.3) \\
\end{array}$ \\
\hline $\begin{array}{l}\text { Being ridiculed for spectacle use }(\mathrm{n}, \%) \\
\text { Yes } \\
\text { No }\end{array}$ & $\begin{array}{l}34(31.5) \\
74(68.5) \\
\end{array}$ \\
\hline $\begin{array}{l}\text { Seeing better with spectacles }(\mathrm{n}, \%) \\
\text { Yes } \\
\text { No }\end{array}$ & $\begin{array}{l}103(95.4) \\
5(4.6)\end{array}$ \\
\hline $\begin{array}{l}\text { Wearing a mask makes it difficult to use } \\
\text { spectacles }(\mathrm{n}, \%) \\
\text { Yes } \\
\text { No }\end{array}$ & $\begin{array}{l}90(83.3) \\
18(16.7)\end{array}$ \\
\hline $\begin{array}{l}\text { Increased prescription in the last year } \\
(\mathrm{n}, \%) \\
\text { Yes } \\
\text { No }\end{array}$ & $\begin{array}{l}43(39.8) \\
65(60.2)\end{array}$ \\
\hline $\begin{array}{l}\text { Enjoying having their eyes checked }(\mathrm{n}, \%) \\
\text { Yes } \\
\text { No }\end{array}$ & $\begin{array}{l}42(38.9) \\
66(61.1)\end{array}$ \\
\hline $\begin{array}{l}\text { Frequency of having eyes checked }(\mathrm{n}, \%) \\
\text { Once every } 6 \text { months } \\
\text { Once a year } \\
\text { At least three times a year }\end{array}$ & $\begin{array}{l}50(46.3) \\
51(47.2) \\
7(6.5)\end{array}$ \\
\hline
\end{tabular}

Comparison of the Mean Scores of Rosenberg Self-Esteem Scale (RSES) and the Social Anxiety Scale for Children-Revised (SASC-R) Between the Study and Control Group 
The comparison of the self-esteem scale and social anxiety scale scores between the spectacle wearers and the control group revealed that the mean selfesteem scores of the spectacle wearers obtained from the Rosenberg Self-Esteem Scale were significantly lower $(22.53 \pm 4.60$ vs. $25.50 \pm 2.05, \mathrm{p}<0.001)$ and the mean social anxiety scale scores obtained from the Social Anxiety Scale for Children-Revised were significantly higher $(40.23 \pm 10.90$ vs. $36.13 \pm 7.57$, $\mathrm{p}=0.006$ ) than the control group. The comparison of the mentioned scales between groups is given in Table 4.

\begin{tabular}{|c|c|c|c|}
\hline & Study group $(\mathrm{n}=108)$ & Control group $(n=150)$ & p-value \\
\hline RSES Score (mean \pm SD) & $22.53 \pm 4.60$ & $25.50 \pm 2.05$ & $<0.001$ \\
\hline SASC-R Score $($ mean \pm SD) & $40.23 \pm 10.90$ & $36.13 \pm 7.57$ & 0.006 \\
\hline
\end{tabular}

\section{Association of the Scores of Rosenberg Self- Esteem Scale and Social Anxiety Scale for Children-Revised with Clinical Variables in the Cohort of Wearing Spectacles Patients}

Analysis of the clinical variables associated with RSES and SASC-R scores revealed that those who did not enjoy wearing spectacles, had difficulties while wearing, who thought that spectacles did not suit them and that spectacles distorted their facial features had significantly lower RSES scores and significantly higher SASC-R scores $(\mathrm{p}<0.001$, for all). Those who were ridiculed for wearing spectacles also had significantly lower RSES scores $(p=0.007)$ and significantly higher SASC-R scores $(p<0.001)$. Similarly, those who did not enjoy getting their eyes checked had significantly lower RSES scores $(p=0.001)$ and significantly higher SASC-R scores $(p=0.004)$. The association of the scores with clinical variables is presented in Table 5 . On the other hand, there was no significant correlation between age, the onset age of spectacle wear, RSES, and SASC-R scores ( $\mathrm{p}>0.05)$.

When the adolescents were evaluated as myopic $(n=78)$ and hyperopic $(n=30)$ regarding the SE even though there was an increase in the SASC$\mathrm{R}$ scores as the degree of myopia increased for both eyes (for right, $r=.280, p=0.01$, and for left, $r=.235$, $\mathrm{p}=0.04$ ) (Diagram 1), there was no significant correlation with RSES scores $(p>0.05)$. No correlation was observed in terms of both SASC-R and RSES scores regarding hyperopia degree $(p>0.05)$. In addition, no significant difference was found between adolescents with myopia and hyperopia regarding $\mathrm{SE}$ in terms of RSES and SASC-R scores $(22.45 \pm 4.8$ vs. $22.8 \pm 4, \mathrm{p}=0.74$ and $40.63 \pm 11.65$ vs. $39.22 \pm 9.16, p=0.55$, for the right eyes, respectively; $22.49 \pm 4.79$ vs. $22.48 \pm 4.32, \mathrm{p}=0.9$ and $40.3 \pm 11.63$ vs. $39.65 \pm 9.04, p=0.75$, for the left eyes, respectively)

\begin{tabular}{|c|c|c|c|c|}
\hline & $\begin{array}{ll}\begin{array}{l}\text { RSES } \\
(\text { mean } \pm \text { SD) }\end{array} & \text { Scores } \\
\end{array}$ & p-value ${ }^{*}$ & $\begin{array}{ll}\begin{array}{l}\text { SASC-R } \\
(\text { mean } \pm \text { SD) })\end{array} & \text { Scores } \\
\end{array}$ & p-value ${ }^{*}$ \\
\hline $\begin{array}{l}\text { Presence of amblyopia (n,\%) } \\
\text { Refractive error (without amblyopia) } \\
\text { Refractive error + Amblyopia }\end{array}$ & $\begin{array}{l}22.44 \pm 4.63 \\
22.86 \pm 4.60 \\
\end{array}$ & 0.665 & $\begin{array}{l}40.64 \pm 11.29 \\
38.64 \pm 9.22 \\
\end{array}$ & 0.526 \\
\hline $\begin{array}{l}\text { Refractive error }(\mathrm{n}, \%) \\
\text { Myopia } \\
\text { Hyperopia } \\
\text { Astigmatism } \\
\text { Myopia + Astigmatism } \\
\text { Hyperopia+ Astigmatism } \\
\end{array}$ & $\begin{array}{l}23.87 \pm 4.14 \\
21.83 \pm 5.19 \\
22.57 \pm 3.69 \\
20.83 \pm 5.08 \\
23.19 \pm 4.08\end{array}$ & 0.085 & $\begin{array}{l}37.26 \pm 11.06 \\
40.33 \pm 10.15 \\
39.14 \pm 9.04 \\
44.50 \pm 11.43 \\
38.62 \pm 8.77\end{array}$ & 0.075 \\
\hline $\begin{array}{l}\text { Individual wearing spectacles in the close social circle } \\
\text { Yes } \\
\text { No }\end{array}$ & $\begin{array}{l}22.72 \pm 4.75 \\
22.31 \pm 4.45\end{array}$ & 0.414 & $\begin{array}{l}39.59 \pm 11.06 \\
41.06 \pm 10.62\end{array}$ & 0.385 \\
\hline $\begin{array}{l}\text { Enjoying wearing spectacles } \\
\text { Yes } \\
\text { No }\end{array}$ & $\begin{array}{l}24.90 \pm 3.29 \\
21.02 \pm 4.70\end{array}$ & $<0.001$ & $\begin{array}{l}32.79 \pm 8.14 \\
44.97 \pm 9.74\end{array}$ & $<0.001$ \\
\hline $\begin{array}{l}\text { Difficulties wearing spectacles }(\mathrm{n}, \%) \\
\text { Yes } \\
\text { No }\end{array}$ & $\begin{array}{l}20.47 \pm 4.57 \\
25.52 \pm 2.60\end{array}$ & $<0.001$ & $\begin{array}{l}45.88 \pm 10.25 \\
32.02 \pm 4.99\end{array}$ & $<0.001$ \\
\hline $\begin{array}{l}\text { Difficulties due to spectacles while playing sports } \\
\text { Yes } \\
\text { No }\end{array}$ & $\begin{array}{l}22.39 \pm 4.88 \\
22.82 \pm 4.00\end{array}$ & 0.902 & $\begin{array}{l}40.31 \pm 10.99 \\
40.06 \pm 10.83\end{array}$ & 0.992 \\
\hline $\begin{array}{l}\text { Thinking spectacles suit one's self } \\
\text { Yes } \\
\text { No }\end{array}$ & $\begin{array}{l}25.10 \pm 3.27 \\
21.07 \pm 4.63\end{array}$ & $<0.001$ & $\begin{array}{l}32.49 \pm 6.46 \\
44.61 \pm 10.47\end{array}$ & $<0.001$ \\
\hline
\end{tabular}




\begin{tabular}{|c|c|c|c|c|}
\hline $\begin{array}{l}\text { Thinking that spectacles distort one's facial } \\
\text { appearance } \\
\text { Yes } \\
\text { No }\end{array}$ & $\begin{array}{l}20.41 \pm 4.66 \\
24.10 \pm 3.91 \\
\end{array}$ & $<0.001$ & $\begin{array}{l}46.54 \pm 9.74 \\
35.55 \pm 9.26 \\
\end{array}$ & $<0.001$ \\
\hline $\begin{array}{l}\text { Being ridiculed for spectacle use } \\
\text { Yes } \\
\text { No }\end{array}$ & $\begin{array}{l}20.74 \pm 5.05 \\
23.35 \pm 4.16\end{array}$ & $\mathbf{0 . 0 0 7}$ & $\begin{array}{l}45.85 \pm 10.07 \\
37.65 \pm 10.32\end{array}$ & $<0.001$ \\
\hline $\begin{array}{l}\text { Seeing better with spectacles } \\
\text { Yes } \\
\text { No }\end{array}$ & $\begin{array}{l}22.72 \pm 4.54 \\
20.13 \pm 5.08\end{array}$ & 0.163 & $\begin{array}{l}39.78 \pm 11.03 \\
45.88 \pm 7.24\end{array}$ & 0.072 \\
\hline $\begin{array}{l}\text { Increased prescription in the last year } \\
\text { Yes } \\
\text { No }\end{array}$ & $\begin{array}{l}22.95 \pm 4.06 \\
22.02 \pm 5.18\end{array}$ & 0.726 & $\begin{array}{l}39.92 \pm 9.81 \\
40.61 \pm 12.16 \\
\end{array}$ & 0.968 \\
\hline $\begin{array}{l}\text { Enjoying having their eyes checked } \\
\text { Yes } \\
\text { No }\end{array}$ & $\begin{array}{l}24.26 \pm 4.03 \\
21.42 \pm 4.63 \\
\end{array}$ & 0.001 & $\begin{array}{l}36.26 \pm 8.23 \\
42.76 \pm 11.66\end{array}$ & $\begin{array}{l}0.004 \\
\end{array}$ \\
\hline $\begin{array}{l}\text { Frequency of having eyes checked }(\mathrm{n}, \%) \\
\text { Every } 6 \text { months } \\
\text { Once a year } \\
\text { At least three times a year }\end{array}$ & $\begin{array}{l}22.56 \pm 4.01 \\
22.55 \pm 5.04 \\
22.14 \pm 5.92\end{array}$ & 0.867 & $\begin{array}{l}40.32 \pm 9.68 \\
40.33 \pm 12.12 \\
38.86 \pm 11.11\end{array}$ & 0.775 \\
\hline
\end{tabular}
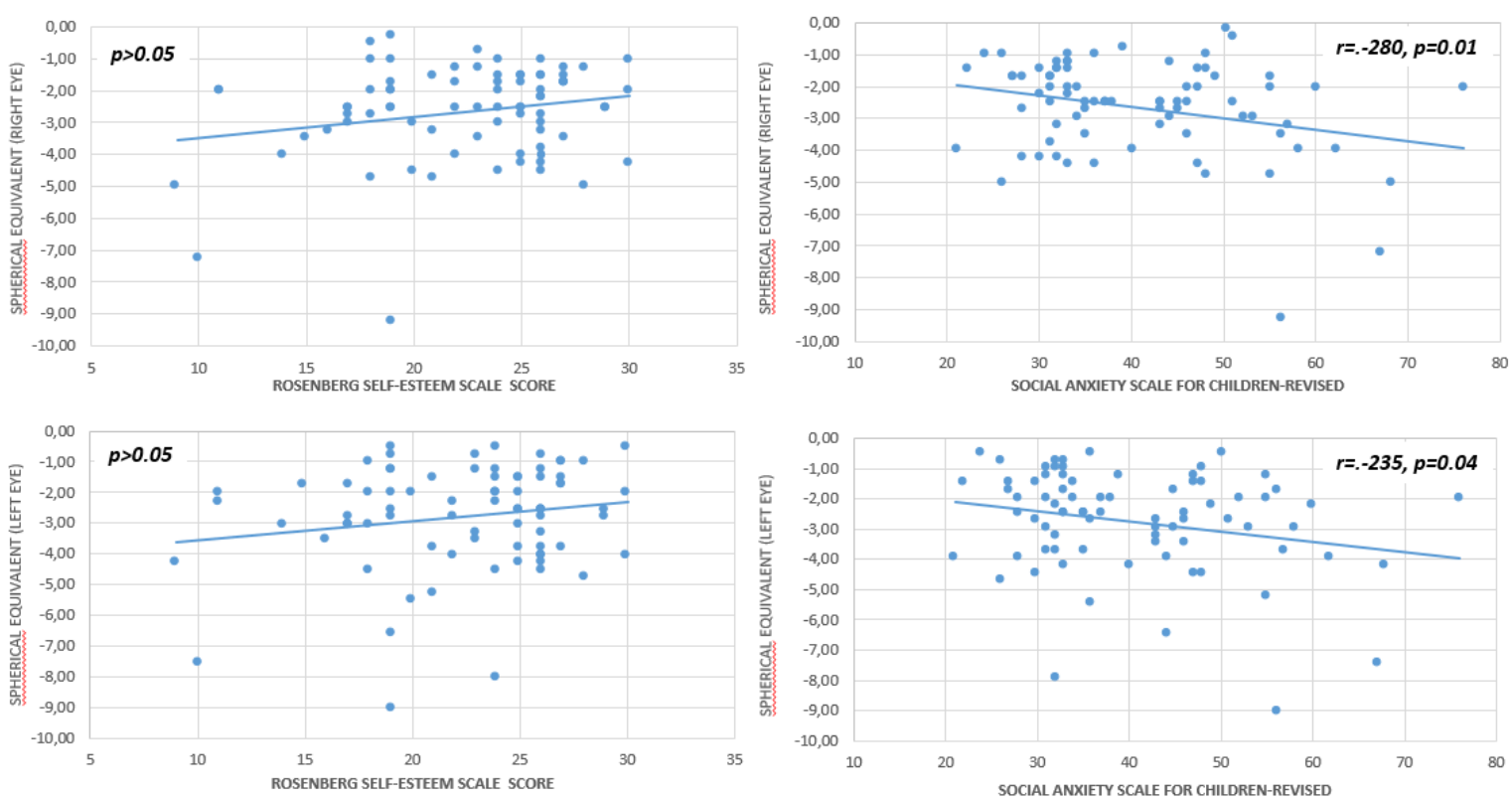

Diagram 1: Correlation between the degree of myopia and Rosenberg Self-Esteem Scale score and Social Anxiety Scale for Children-Revised

\section{DISCUSSION}

In this study, the social anxiety level and self-esteem of adolescents who wear and do not wear spectacles were investigated and we observed that adolescents who wore spectacles had lower self-esteem and higher social anxiety level than those who did not. Furthermore, we found that those who do not enjoy wearing spectacles, having their eyes checked, who have difficulties wearing them, who are ridiculed for using spectacles, who think that spectacles do not suit them and distort their facial features, have lower self-esteem and higher social anxiety scores compared to their peers. In addition, sole evaluation of the adolescents with myopia revealed that alongside the increase in the degree of myopia social anxiety levels were also increased, however, selfesteem was not affected.
Studies are demonstrating that wearing spectacles is associated with low self-esteem regarding physical appearance and social interactions. 4 Spectacle use in children and adolescents is reported to arouse negative emotions, ridicule, and emotional problems related to physical appearance. $\stackrel{20}{2}$ Tuncer et al. compared adolescents wearing spectacles with those who did not according to Piers-Harris Children's Self-concept Scale and reported lower physical appearance scores in adolescents wearing spectacles. 11 Spectacles prescribed at a younger age and therefore worn longer may be associated with low self-esteem since childhood is the developmental period in which selfesteem is formed. $-\frac{4}{}$ Terry et al. reported that wearing spectacles for the first time in childhood (younger than 13 years of age) or adulthood will affect self- 
esteem more negatively than wearing spectacles in adolescence, and children who wear spectacles may experience more social problems than adolescents. $\underline{21}$ In our study, the onset of spectacle wear for the majority $(91.6 \%)$ was childhood (younger than 13 years of age). This may explain why adolescents who wear spectacles in our study have lower selfesteem. However, there was no significant correlation between age, the onset age of spectacle wear, RSES, and SASC-R scores.

Studies conducted in children with amblyopia reported that children who were treated with patching or spectacle use are particularly embarrassed by the reaction of their peers, and children who wear spectacles or eye patches are exposed to physical or verbal bullying approximately $35 \%$ more. $\underline{22}$ Webber et al. reported that patching, not spectacle use, was associated with a low social acceptance score related to self-esteem in children treated for amblyopia. $\stackrel{23}{2}$ In our study, we found that $31.5 \%$ of the adolescents were bullied by their peers due to spectacle use. Furthermore, no relationship was found between the presence of amblyopia and self-esteem and social anxiety scores, but none of the adolescents in our study were being treated with patching. Therefore, the efficacy of patching could not be evaluated. In addition, all but two of the adolescents with amblyopia had mild to moderate amblyopia in our study group.

There are controversial studies about one's self-perception and perception of others who wear spectacles. In previous studies, spectacle use was associated with unattractiveness as well as a more intelligent appearance. $\underline{5}$ Walline et al. reported improvements in appearance, satisfaction with correction, activities, and peer perceptions in children and teens with wearing contact lenses. In addition, $71.2 \%$ of children and $78.5 \%$ of teens indicated that they liked wearing contact lenses a little or a lot better than spectacles. $\underline{24}$ In another study, Walline et al. evaluated children aged 8-11 years, who wore spectacles or contact lenses for 3 years and demonstrated that although there was no alteration regarding children's global self-esteem, children using contact lenses showed an improvement in self-perception regarding physical appearance, athletic competence, and social acceptance. $\underline{25}$ The biggest difference between contact lens wearers and spectacle wearers was in physical appearance scores regardless of whether or not they enjoyed wearing glasses initially. Spectacle wear has been associated with disfigurement and less attractiveness, therefore it's not surprising that children's self-perception of their physical appearance benefits from contact lens wear. $\underline{25}$ In our study, adolescents who thought that spectacle use affects their appearance had lower self-esteem scores and higher social anxiety scores. Also, adolescents who do not enjoy wearing spectacles had lower selfesteem and higher social anxiety scores compared to the ones who enjoy. In addition, $68 \%$ of our participants wearing spectacles stated that they had difficulties while playing sports. One of the greatest improvements in quality of life was demonstrated in the athletics area in children and teens who switched from spectacle wear to contact lens wear. $\underline{24}$ In this age period, in particular, team sports support social development and affect self-esteem positively. Teamwork promotes building a truly collaborative environment and developing feelings such as empathy. Moreover, being together with people who enjoy doing the same thing improves communication skills and other skills related to establishing social relationships. Consequently, having difficulties while participating in sports due to spectacle use may cause children and adolescents to avoid these activities that will greatly contribute to their mental, emotional and social development. This, in turn, will deprive the child and adolescent of the opportunity to test themselves, compare themselves with their peers, and may affect their psychosocial well-being, such as the development of positive self-esteem, self-perception, and mental resilience. $\underline{26}$

Terry et al. divided 125 spectacle-wearing children between the ages of 10-13 into two groups as those who continue to wear spectacles or those who have switched to contact lenses and evaluated their self-esteem at the end of a 3-year follow-up. The children's self-concepts after wearing contact lenses revealed that all children felt better about their appearance and popularity over time, but there was no difference regarding self-esteem between the two groups after 3 years. $\stackrel{27}{7}$ This may be due to patients getting used to their vision correction and the benefits become less pronounced over time. $\underline{24}$ Nonetheless, they found a relationship between higher degrees of myopia and lower self-esteem. 27 Dias et al. reported that self-esteem was related to visual symptoms but not with refractive error severity in myopic children wearing spectacles. ${ }^{4}$ In a study conducted in China, similar to our findings children who wear spectacles due to myopia were found to have a high level of social anxiety, and a high degree of myopia, prolonged spectacle use $(>2$ years), and low self-esteem were related with social anxiety. $\underline{28}$ The increase in social anxiety scores with the degree of myopia may be due to higher myopia requiring thicker lenses, more noticeable spectacles, and lower visual acuity without spectacles. 27 In our study, adolescents who wore spectacles had lower self-esteem scores and higher social anxiety scores. Besides, there was no relationship between selfesteem and the degree of myopia, while social anxiety score was found to be higher as the degree of myopia increased. 
The strengths of this study are that the psychopathology of all participants was comprehensively evaluated with the detailed psychiatric interview by a trained and certified child and adolescent psychiatrist, all ocular and visual disorders were examined in detail, and the sample was chosen from those without psychiatric disorders to be more representative of the general population.

\section{Limitations of the Study}

However, this study has some limitations. Since the data were collected through self-report questionnaires as subjective assessments it may have caused response bias. Our study sample size was relatively small, based on a population derived from a single hospital. These weaknesses intercept the generalization of our results and the determination of precise causality. In addition, the inclusion of adolescents with amblyopia may be another limitation. However, none of the adolescents with amblyopia were being treated with patching. With these limitations in mind, the results of this study should be interpreted with caution and validated by further studies.

\section{CONCLUSION}

In adolescence, wearing spectacles seems to be related to self-esteem and social anxiety. Adolescents who wore spectacles had lower selfesteem and higher social anxiety level than those who did not. Self-esteem is paramount in terms of adapting to wearing spectacles. In case adolescents who wear spectacles think negatively about themselves and their appearance, they will poorly adapt to wearing spectacles, which will affect both their social life and school success together with low visual acuity. Also, social anxiety may lead to withdrawal from social situations. Thereby, an appropriate approach would be to perform a thorough psychological evaluation of adolescents who wear spectacles, transform negative perceptions about spectacles into positive ones with the help of role models, and provide the necessary support.

\section{Conflict of Interest}

All authors declare that they have no conflict of interest

\section{Funding}

There is no funding

\section{Contribution of the authors}

DYY: Idea generation, study design, data collection, writing

EB: Draft of the manuscript, correction

AUC: Study design, statistics, review and editing

\section{REFERENCES}

1. Steinmetz JD, Bourne RR, Briant PS, Flaxman SR, Taylor HR, Jonas JB, et al. Causes of blindness and vision impairment in 2020 and trends over 30 years, and prevalence of avoidable blindness in relation to VISION 2020: the Right to Sight: an analysis for the Global Burden of Disease Study. Lancet Glob Health. 2021; 9: e144-e60.

2. Hashemi H, Fotouhi A, Yekta A, Pakzad R, Ostadimoghaddam $\mathrm{H}$ and Khabazkhoob $\mathrm{M}$. Global and regional estimates of prevalence of refractive errors: Systematic review and metaanalysis. J Curr Ophthalmol. 2018; 30: 3-22.

3. Wong CW, Tsai A, Jonas JB, Ohno-Matsui K, Chen J, Ang M, et al. Digital screen time during the COVID-19 pandemic: risk for a further myopia boom? Am J Ophthalmol. 2021; 223: 333-7.

4. Dias L, Manny RE, Hyman L, Fern K and GROUP C. The relationship between selfesteem of myopic children and ocular and demographic characteristics. Optom Vis Sci. 2002; 79: 688-96.

5. Jellesma FC. Do glasses change children's perceptions? Effects of eyeglasses on peer-and self-perception. Eur J Dev Psychol. 2013; 10: 449-60.

6. Hahn-Smith AM and Smith JE. The positive influence of maternal identification on body image, eating attitudes, and self-esteem of Hispanic and Anglo girls. Int J Eat Disord. 2001; 29: 429-40

7. Leonard BJ, Brust JD, Abrahams G and Sielaff B. Self-concept of children and adolescents with cleft lip and/or palate. Cleft Palate Craniofac J.. 1991; 28: 347-53.

8. Odedra N, Wedner SH, Shigongo ZS, Nyalali K and Gilbert C. Barriers to spectacle use in Tanzanian secondary school students. Ophthalmic Epidemiol. 2008; 15: 410-7.

9. Walline JJ, Sinnott L, Johnson ED, Ticak A, Jones SL and Jones LA. What do kids think about kids in eyeglasses? Ophthalmic Physiol Opt. 2008; 28: 218-24.

10. Lyon D, Rainey B and Bullock C. The effects of glasses on the self-concept of school-aged children. J Optom Vis Dev. 2002; 33: 29-32.

11. Tuncer Ö, Atay İM, Gök Balcı U, Tekgül N and Öngel K. Ergenlerde Gözlük Kullanımı İle Özgüven Arasındaki İlişki: Basit Kesitsel Bir Çalışma. Tepecik Eğit Hast Derg. 24: 1-6.

12. Halldorsson B and Creswell C. Social anxiety in pre-adolescent children: What do we know about maintenance? Behav Res Ther. 2017; 99: 19-36. 
13. Gill C, Watson L, Williams C and Chan SW. Social anxiety and self-compassion in adolescents. J Adolesc. 2018; 69: 163-74.

14. Eroğlu K and Odacı H. Ortaokul Yedinci ve Sekizinci Sınıf Öğrencilerinin Sosyal Anksiyete Düzeyleri ile Benlik Saygıları, Anne-Baba Tutumları, Mükemmeliyetçilik Özellikleri Arasındaki İlişki. Turk J Child Adolesc Ment Health. 2019; 26: 108-15.

15. American Psychiatric Association A and Association AP. Diagnostic and statistical manual of mental disorders: DSM-5. Washington, DC: American psychiatric association, 2013;31-715.

16. Rosenberg, M., Society and the adolescent selfimage. New Jersey:Princeton university press. 1965;3-39.

17. Çuhadaroğlu F. Adolesanlarda benlik saygısı. Uzmanlık Tezi, Hacettepe Üniversitesi Tip Fakültesi Psikiyatri Anabilim Dalı, Ankara. 1986;70-75.

18. La Greca AM and Stone WL. Social anxiety scale for children-revised: Factor structure and concurrent validity. J Clin Child Psychol. 1993; 22: 17-27.

19. Demir T, Eralp-Demir D, Türksoy N, Özmen E and Uysal Ö. Çocuklar için sosyal anksiyete ölçeğinin geçerlilik ve güvenilirliği. Düşünen Adam. 2000; 13: 42-8.

20. Bernfeld A. Psychological impact of eyeglasses. Bull Soc Belge Ophtalmol. 1994; 253: 57-62.

21. Terry R, Berg A and Phillips P. The effect of eyeglasses on self-esteem. J Am Optom Assoc. 1983; 54: 947-9.
22. Horwood J, Waylen A, Herrick D, Williams C and Wolke D. Common visual defects and peer victimization in children. Invest Ophthalmol Vis Sci. 2005; 46: 1177-81.

23. Webber AL, Wood JM, Gole GA and Brown B. Effect of amblyopia on self-esteem in children. Optom Vis Sci. 2008; 85: 1074-81.

24. Walline JJ, Gaume A, Jones LA, Rah MJ, Manny RE, Berntsen DA, et al. Benefits of contact lens wear for children and teens. Eye Contact Lens. 2007; 33: 317-21.

25. Walline JJ, Jones LA, Sinnott L, Chitkara M, Coffey B, Jackson JM, et al. Randomized trial of the effect of contact lens wear on selfperception in children. Optom Vis Sci. 2009; 86: 222-32.

26. Liu M, Wu L and Ming Q. How Does Physical Activity Intervention Improve Self-Esteem and Self-Concept in Children and Adolescents? Evidence from a Meta-Analysis. PLoS One. 2015; 10: e0134804.

27. Terry RL, Soni PS and Horner DG. Spectacles, contact lenses, and children's self-concepts: a longitudinal study. Optom Vis Sci. 1997; 74: 1044-8.

28. Wang D, Yang J, Xian Y-J, Wu P-P and Lin SL. Current status of social anxiety among primary school students with myopia in Urumqi, China and risk factors for myopia. Zhongguo Dang dai er ke za zhi= Chinese Journal of Contemporary Pediatrics. 2019; 21: 184-8. 